\title{
KEMAMPUAN DAYA HAMBAT EKSTRAK DAUN MURBEI (Morus alba) TERHADAP PERTUMBUHAN Aspergillus flavus
}

\section{The Ability of Muleberry Leaf Extract (Morus alba) to Inhibit the Growth of Aspergillus flavus}

\author{
${ }^{1}$ Aditya Yusril Hidayat, ${ }^{2}$ Agus Selamet Duniaji*, ${ }^{2}$ Komang Ayu Nocianitri \\ ${ }^{1}$ Mahasiswa Program Studi Ilmu dan Teknologi Pangan, Fakultas Teknologi Pertanian, Unud \\ ${ }^{2}$ Dosen Program Studi Ilmu dan Teknologi Pangan, Fakultas Teknologi Pertanian, Unud \\ Kampus Bukit Jimbaran, Badung-Bali
}

\begin{abstract}
The aim of this research to determine the ability of mulberry leaf extract (Morus alba) to inhibit the growth of Aspergillus flavus. This research used completely Randomized Design with control treatment (without extract) and treatment of mulberry leaf extract concentration of 10\%, 20\%, 30\%, 40\%, 50\%, 60\%, 70\%, 80\%, $90 \%, 100 \%$. The experiment were repeated 2 times and resulting in 22 experimental units. The data were presented in descriptive statistic with tables, and figure. The results showed that the extract of mulberry leaf inhibit the growth of Aspergillus flavus with optimal concentration $80 \%$ with an average $11.95 \mathrm{~mm}$ and strong inhibition categories.
\end{abstract}

Keyword: Mulberry Leaf, Aspergillus flavus, Antimold

\section{PENDAHULUAN}

Penelitian pada tumbuhan berkembang pesat terutama dari sisi aktivitas biologis seperti aktivitas antioksidan dan antibakteri. Penelitian ini menjadi perhatian yang menarik dalam upaya penggalian senyawa baru yang bermanfaat bagi kesehatan manusia dan manfaatnya di bidang pangan. Dalam kaitannya dengan manfaat di bidang pangan, ekstrak tanaman yang mengandung antioksidan dapat digunakan untuk mengawetkan bahan makanan (Martin, 2012).

Murbei (Morus alba L.) merupakan tanaman yang dapat tumbuh secaraliar di seluruh wilayah Indonesia namun kurang dimanfaatkan oleh masyarakat sekitar (Sunanto, 2009). Daun murbei memiliki beberapa efek farmakologis antara lain bersifat diuretik, antidemam dan antihipertensi (Permadi, 2006). Kandungan senyawa aktif yang terdapat pada murbei yaitu alkaloid, flavonoid, dan polifenol (Sunanto, 2009). Senyawa bioaktif tersebut didapat dengan cara melakukan ekstraksi. Ekstraksi senyawa bioaktif daun murbei dilakukan menggunakan pelarut yang sesuai. Senyawa bioaktif dalam daun murbei merupakan senyawa polar, sehingga dapat diekstrak menggunakan pelarut polar. Pelarut polar yang dapat digunakan adalah etanol dan air.

Anita et al. (2014) menyatakan bahwa senyawa alkaloid, flavonoid, dan polifenol dapat berperan sebagai antimikroba. Penelitian sebelumnya (Elsie et al, 2010) yang menunjukkan bahwa ekstrak bahan yang mengandung senyawa alkaloid dan flavonoid

*Korespondensi Penulis :

E-mail: selametduniaji@unud.ac.id 
terbukti berpotensi sebagai antibakteri pada Staphylococcus aureus, Bacillus cereus, Micrococcus luteus dan sebagai antikapang Candida albicans, Aspergillus flavus, dan Aspergillus niger. Senyawa fenolik bermolekul besar mampu menginaktifkan enzim esensial di dalam sel meskipun pada konsentrasi yang sangat rendah, sehingga menyebabkan mekanisme germinasi spora terganggu, sehingga jamur tidak berkembang (Rahmawati, 2004). Fenol adalah senyawa yang bersifat hidrofilik sehingga mudah terikat dan mengakibatkan kerusakan pada dinding sel. Selain itu, tanin juga dapat menghambat sintesis khitin yang merupakan komponen utama dinding sel kapang (Huang, et al., 1998; Artana, 2016).

Kapang merupakan salah satu organisme yang mempunyai inti sel, dapat membentuk spora, tidak berkrolofil, terdapat benang - benang tunggal atau benang - benang yang bercabang dengan dinding selulosa atau khitin (Suarnadwipa, et al., 2008). Salah satu kapang yang berbahaya bagi manusia adalah Aspergillus flavus. Aspergillus flavus merupakan kapang yang umumnya dapat ditemukan dalam tanah, sisa-sisa tumbuhan, bahan makanan dan di ruangan. Aspergillus flavus memproduksi aflatoksin yang telah terbukti berpotensi menjadi karsinogenik. Bahan pangan yang dapat terkontaminasi aflatoksin adalah sereal (jagung, sorgum, millet mutiara, beras, gandum), minyak sayur (kacang tanah, kedelai, bunga matahari, kapas), rempah-rempah (cabe, lada hitam, ketumbar, kunyit, jahe), kacang (almond, pistachio, kenari) dan susu (Reddy et al, 2000) Bahaya aflatoksin membutuhkan penanganan yang tepat (Nuryani, 2011), Aflatoksin dapat menyebabkam nekrosis hati akut, sehingga nantinya menjadi sirosis/karsinoma hati, gagal hati, perdarahan, perubahan dalam pencernaan, perubahan penyerapan atau metabolisme nutrisi, dan perubahan mental serta koma. Oleh karena itu sangat diperlukan upaya untuk mengurangi pertumbuhan Aspergillus flavus pada berbagai bahan pangan. Penelitian dilakukan untuk mengetahui potensi ekstrak daun murbei (Morus alba) dalam menghambat pertumbuhan Aspergillus flavus.

\section{METODE PENELITIAN}

\section{Tempat dan Waktu}

Penelitian ini dilaksanakan di Laboratorium Mikrobiologi Pangan dan Laboratorium Analisis Pangan Program Studi Ilmu dan Teknologi Pangan, Fakultas Teknologi Pertanian, Universitas Udayana. Pelaksanaan penelitian ini akan dilakukan pada bulan Desember 2018 sampai dengan bulan Maret 2019.

\section{Bahan dan Alat}

Bahan yang digunakan dalam penelitian ini adalah daun murbei yang didapatkan dari Desa Angseri, Kecamatan Baturiti, Kabupaten Tabanan, Bali dan Isolat kapang Aspergillus flavus yang diperoleh di Laboratorium Mikrobiologi Fakultas Teknologi Pertanian Universitas Udayana, aquades steril, media Potato dextrose-agar (PDA), $\mathrm{NaCl}$, alkohol $95 \%$. 
Alat - alat yang digunakan dalam penelitian ini adalah pisau, evaporator ( $\mathrm{Ka}$ Labortechnik), batang bengkok, timbangan analitik (Ohaus), mikropipet (Akura), inkubator (Memmert), tip, laminar flow cabinet (Kojair), bunsen, tabung durham, kertas label, vortex (Gemmy), korek api, mikroskop, cawan petri (Pyrex), jarum ose, tabung reaksi (Pyrex), gelas beker (Pyrex), erlenmeyer (Pyrex), gelas ukur (Pyrex), jangka sorong dan tabung effendorf, tissue, plastik HDPE, aluminium foil (Klin Park), autoklaf (Hirayama).

\section{Rancangan Percobaan}

Penelitian ini menggunakan Rancangan Acak Lengkap dengan perlakuan konsentrasi ekstrak daun murbei. Perlakuan konsentrasi ekstrak terdiri dari 11 taraf yaitu:

P0 : Tanpa menggunakan ekstrak daun murbei

P1 : Konsentrasi 10\% ekstrak daun murbei

P2 : Konsentrasi 20\% ekstrak daun murbei

P3 : Konsentrasi 30\% ekstrak daun murbei

P4 : Konsentrasi 40\% ekstrak daun murbei

P5 : Konsentrasi 50\% ekstrak daun murbei

P6 : Konsentrasi 60\% ekstrak daun murbei

P7 : Konsentrasi 70\% ekstrak daun murbei

P8 : Konsentrasi 80\% ekstrak daun murbei

P9 : Konsentrasi 90\% ekstrak daun murbei

P10 : Konsentrasi 100\% ekstrak daun murbei

Perlakuan ini diulang sebanyak dua kali sehingga diperoleh 22 unit. Data hasil penelitian dianalisis dan disajikan secara deskriptif dengan menampilkan Tabel dan Gambar. Kemudian setelah didapat konsentrasi ekstrak dengan daya hambat paling besar dilanjutkan dengan melakukan uji populasi Aspergillus flavus dengan menghitung populasi yang tumbuh dengan menginkubasi Aspergillus flavus pada media PDA dengan ditambahkan ekstrak dan tidak ditambahkan ekstrak, dengan rentang waktu inkubasi 5 dan 10 hari.

\section{Pelaksanaan Penelitian}

Tahap pelaksanaan percobaan meliputi beberapa tahapan yaitu persiapan sampel, pembuatan ekstrak, uji konfirmasi, uji aktivitas antikapang dan uji total populasi.

\section{Pembuatan Estrak Daun Murbei}

Pembuatan ekstrak daun murbei dilakukan dengan menggunakan metode maserasi. Sebanyak 50 gram serbuk daun murbei dimasukkan ke dalam aquades sebanyak $250 \mathrm{ml}$ (1:5) dan didiamkan selama 24 jam dengan diaduk sebanyak 2 kali. Ekstrak disaring untuk memisahkan ampas dan filtratnya. Selanjutnya filtrat dievaporasi dengan rotary evaporator pada suhu $40{ }^{\circ} \mathrm{C}$ sehingga didapatkan ekstrak kental. Ekstrak kental yang diperoleh ditimbang dan disimpan di dalam desikator sebelum digunakan untuk uji selanjutnya (Selawa et al, 2013 yang dimodifikasi).). Pembuatan 10 taraf konsentrasi dilakukan dengan cara menambahkan aquadest steril kedalam ekstrak pekat sesuai dengan taraf konsentrasi $(10 \%, 20 \%, 30 \%, 40 \%, 50 \%, 60 \%$, $70 \%, 80 \%$, 90\% dan 100\%) persen terhadap ekstrak. 


\section{Uji Konfirmasi Aspergillus flavus}

Isolasi Aspergillus flavus dilakukan dengan cara mengambil 1 ose koloni aspergillus flavus yang berwarna hijau dan ditumbuhkan ke media cair aquades steril $9 \mathrm{ml}$ dan diinkubasi selama 1 hari. Pemurnian dilakukan dengan menumbuhkan 1 ose Aspergillus flavus ke media AFPA (Aspergillus flavus Parasiticus Agar) dan selanjutnya diinkubasi selama lima hari (120 jam) pada suhu $30^{\circ} \mathrm{C}$. Proses ini dilakukan sebanyak tiga kali sampai diproleh koloni Aspergillus flavus yang benar-benar murni. Pengamatan dan konfirmasi dilakukan menggunakan mikroskop dengan melihat berdasar warna koloni kapang dan bentuk morfologinya.

\section{Pengujian Aktivitas Antikapang Ekstrak}

Daun Murbei terhadap Aspergillus flavus

\section{dengan Metode Sumur}

Pengujian aktivitas antikapang ekstrak daun murbei terhadap Aspergillus flavus ini dilakukan dengan menggunakan ekstrak daun murbei. Pengujian ini diawali dengan cara membuat ekstrak dengan konsentrasi P0, P1, P2, P3, P4, P5, P6, P7, P8, P9 dan P10. Kemudian diambil 1 ose kapang dari media PDA, kemudian diinokulasikan ke dalam tabung berisi $9 \mathrm{ml}$ aquades steril. Selanjutnya divorteks untuk meratakan kapang di dalam tabung reaksi. (Apriyanto, 2002). Media PDA yang sudah disetrilkan dimasukkan ke dalam cawan petri steril, kemudian dibiarkan memadat pada suhu kamar. Media tersebut ditambahkan dengan Aspergillus flavus sebanyak 0,1 ml lalu diratakan dengan batang $L$ hingga rata dan kering. Media tersebut dilubangi sebesar $6 \mathrm{~mm}$, kemudian ektrak daun murbei dimasukan kedalam lubang tersebut sebanyak $0.02 \mathrm{ml}$ dan diinkubasi selama 3 hari dengan suhu $30^{\circ} \mathrm{C}$ (Nuryani, 2011).

Variabel yang diamati adalah besarnya diameter zona hambat yang dibentuk oleh ekstrak daun murbei dalam satuan millimeter (mm) terhadap pertumbuhan Aspergillus flavus pada media PDA dari masing-masing perlakuan konsentrasi. Zona hambat merupakan daerah penghambatan berupa area bening yang mucul disekeliling kertas cakram. Zona penghambatan diukur dengan jangka sorong sebanyak empat kali di tempat yang berbeda dan hasilnya dirata-ratakan kemudian dikurangi dengan diameter sumur (Amanah, 2011).

\section{Pengujian Total Populasi Aspergillus flavus}

Pengujian ini dilakukan setelah mendapatkan ekstrak daun dengan kategori penghambat kuat terhadap Aspergillus flavus. Pengujian ini dilakukan dengan menghitung total penurunan pertumbuhan Aspergillus flavus tanpa ditambahkan ektrak (kontrol) dan ditambahkan ekstrak daun murbei dengan kategori penghambat kuat. Pembuatan kontrol dilakukan dengan kultur Aspergillus flavus diencerkan dalam aquades steril dengan perbandingan konsentrasi $1 \mathrm{ml}$ kultur kapang dan $9 \mathrm{ml}$ aquades steril. Kemudian dilakukan pengenceran hingga $10^{-7}$, selanjutnya dipipet sebanyak $0,1 \mathrm{ml}$ dan ditanam dalam media 
PDA kemudian diinkubasi selama 5 hari. Pada pengujian pertumbuhan Aspergillus flavus setelah ditambahkan ekstrak daun murbei dengan kategori penghambat kuat dilakukan dengan kultur Aspergillus flavus diencerkan dalam aquades steril dengan perbandingan konsentrasi $1 \mathrm{ml}$ kultur kapang dan $9 \mathrm{ml}$ aquades steril. Kemudian dilakukan pengenceran hingga $10^{-7}$ dipipet $1 \mathrm{ml}$ kultur dan ditambahkan $1 \mathrm{ml}$ ekstrak kedalam tabung reaksi serta, kemudian dipipet sebanyak 0,1 $\mathrm{ml}$ dan ditanam dalam media PDA kemudian diinkubasi selama 5 dan 10 hari. (Parhusip, 2008 yang telah dimodifikasi). Perhitungan populasi Aspergillus flavus yang dapat dihambat oleh ekstrak daun murbei yang telah diuji pada media PDA dihitung dengan membandingkan populasi kontrol dengan populasi yang telah ditambahan ektrak kensentrasi penghambat minimal.

\section{HASIL DAN PEMBAHASAN}

\section{Uji Konfirmasi Aspergillus flavus}

Pengujian konfirmasi Aspergillus flavus meliputi warna dan bentuk morfologi. Isolasi Aspergillus flavus menggunakan media PDA (Potato Dextrose Agar). Diinkubasi selama 5 hari pada suhu ruang. Selanjutnya dilakukan proses pemurnian. Proses pemurnian menggunakan media AFPA (Aspergillus Flavus Paraciticus Agar) dengan masa inkubasi selama 5 hari pada suhu ruang. Hasil Isolasi pada media PDA dapat dilihat pada Gambar 1.

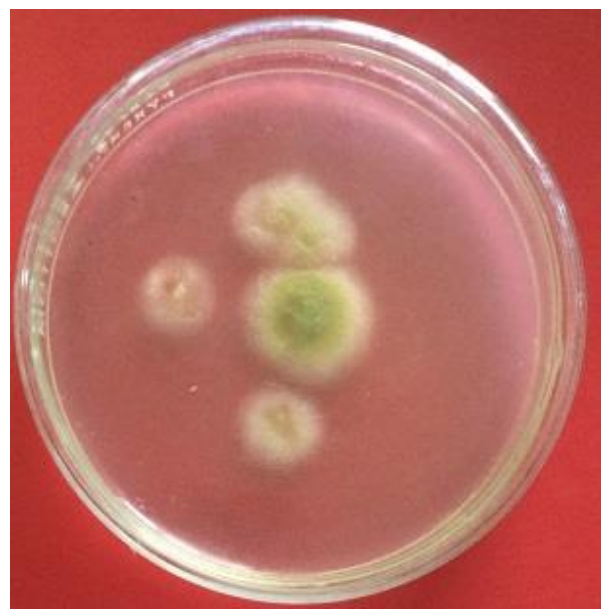

Gambar 1. Aspergillus flavus pada media PDA yang diinkubasi selama 5 hari pada suhu ruang. Pada Gambar 1 menunjukkan A. flavus memiliki koloni awal yang berwarna putih dan menjadi hijau gelap kekuningan. Menurut Pitt dan Hocking (1997), ciri - ciri Aspergillus flavus secara makroskopis adalah koloni berwarna hijau dan koloni yang masih muda berwarna putih, kepala konodiofor tipe radial, konodiofor panjang dan kasar, semakin dekat dengan vesikel akan semakin kasar. Konodia berbentuk bulat atau lonjong (berdiameter 3-6 um), yang berwarna hijau pucat. Beberapa strain memproduksi sclerotia. Dalam kondisi penyimapanan tertutup dan aerasi kurang mendorong pertumbuhan jamur ini. Habitat Aspergillus flavus secara umum terdapat pada kacang-kacangan, rempah, bijibijian, minyak, dan serealia. Hasil pengamatan dengan mikroskop terhadap morfologi Aspergillus flavus dapat dilihat pada Gambar 2. 

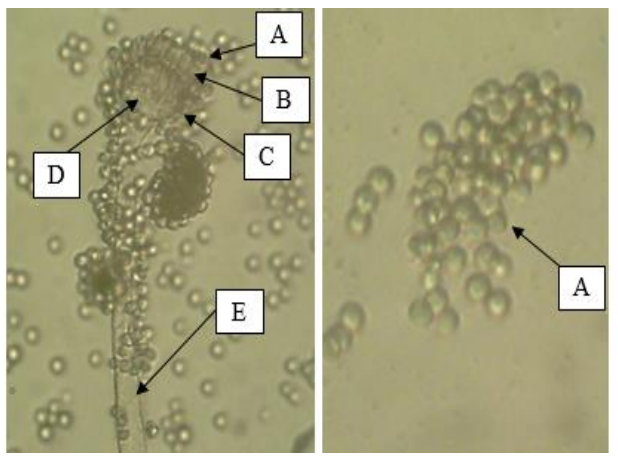

Gambar 2. Aspergillus flavus diamati menggunakan mikroskop pada pembesaran 400

Keterangan: (A): Konodia, (B): Pialida, (C): Metula, (D): Vesikel, (E): Konidiofora

Pada Gambar 2 dapat dilihat secara morfologi bagian dari Aspergillus flavus yaitu pialida, visicle, konodia, metula dan konidiopora. Aspergillus flavus memproduksi konodia dengan ukuran dan bentuk yang bervariasi, dinding sel konodia tipis dan

Tabel 1. Rata-rata diameter penghambatan ekstrak daun murbei terhadap pertumbuhan Aspergillus flavus.

\begin{tabular}{ccc}
\hline Perlakuan Konsentrasi & Rata-rata $(\mathrm{mm})$ & Kategori Daya Hambat \\
\hline Tanpa ekstrak & 0 & Tidak ada \\
$10 \%$ & 2,47 & Lemah \\
$20 \%$ & 3,02 & Lemah \\
$30 \%$ & 4,27 & Lemah \\
$40 \%$ & 6,11 & Sedang \\
$50 \%$ & 7,41 & Sedang \\
$60 \%$ & 8,52 & Sedang \\
$70 \%$ & 9,91 & Sedang \\
$80 \%$ & 11,95 & Kuat \\
$90 \%$ & 10,24 & Kuat \\
$100 \%$ & 9,46 & Sedang \\
\hline
\end{tabular}


Tabel 1 menunjukan ekstrak daun murbei dapat menghambat pertumbuhan Aspergillus flavus dari konsentrasi terendah hingga tertinggi dengan lemah hingga kategori kuat. Menurut Davis dan Stout (1971), kategori daya hambat pada diameter penghambatan dikelompokkan menjadi empat kategori, yaitu $<5 \mathrm{~mm}$ lemah, 5$10 \mathrm{~mm}$ sedang 10-20 mm kuat dan > $20 \mathrm{~mm}$ sangat kuat Diameter penghambatan Aspergillus flavus terbesar diperoleh pada konsentrasi ekstrak daun murbei $80 \%$ yaitu sebesar 11,95 mm. Sedangkan diameter penghambatan terkecil diperoleh pada konsentrasi ekstrak daun murbei $10 \%$ yaitu sebesar 2,47 mm. Konsentrasi yang digunakan merupakan faktor yang juga mempengaruhi besar kecilnya penghambatan yang terbentuk disekitar lubang yang telah diisi ekstrak. Semakin lebar diameter penghambatan yang terbentuk membuktikan kuatnya senyawa bioaktif itu menghambat pertumbuhan bakteri (Davis dan Stout, 1971). Dilihat dari Tabel 1 diameter penghambatan terus meningkat mulai dari konsentrasi terendah $10 \%$ hingga konsentrasi $80 \%$, tetapi menurun dari konsentrasi $90 \%$ hingga konsentrasi tertinggi 100\%. Penurunan diameter penghambatan pada konsentrasi $90 \%$ dan $100 \%$ terjadi karena ekstrak tidak mampu berdifusi dengan baik, hal ini sesuai dengan Pelezar et al. (1988) menyatakan bahwa semakin tinggi konsetrasi suatu zat antibakteri maka semakin cepat mikroba terhambat pertumbuhannya, namun menurut Ganiswara (1995) menyatakan bahwa peningkatan konsentrasi suatu bahan akan diikuti dengan peningkatan daya hambat pertumbuhan bakteri, tetapi pada konsentrasi maksimal akan terjadi penurunan daya hambat pertumbuhan bakteri.

Diameter penghambatan pada media PDA muncul setelah penyimpanan selama 24 jam. Terbenuknya diameter penghambatan menunjukkan bahwa ekstrak daun murbei memiliki senyawa bioaktif yang berperan sebagai senyawa antikapang sehingga mampu menghambat pertumbuhan Aspergillus flavus. Terbentuknya zona hambat daun murbei terhadap Aspergillus flavus dapat dilihat pada Gambar 3. Kemampuan ekstrak daun murbei dalam menghambat pertumbuhan Aspergillus flavus dipengaruhi oleh kandungan daun murbei yaitu senyawa-senyawa flavonoid, alkaloid, polifenol yang berperan sebagai aktivitas antikapang (Sunanto, 2009). Senyawa tersebut mampu berperan sebagai antikapang Senyawa flavonoid merupakan senyawa golongan fenol yang mempunyai aktivitas antikapang. Senyawa ini bekerja dengan cara mendenaturasi enzim yang terlibat dalam proses germinasi spora karena senyawa fenolik bermolekul besar mampu menginaktifkan enzim esensial di dalam sel meskipun pada konsentrasi yang sangat rendah, sehingga menyebabkan mekanisme germinasi spora terganggu, sehingga jamur tidak berkembang (Rahmawati, 2004). Fenol adalah senyawa 
yang bersifat lipofilik sehingga mudah terikat dan mengakibatkan kerusakan pada dinding sel. Selain itu, tanin juga dapat menghambat sintesis khitin yang merupakan komponen utama dinding sel jamur (Huang, et al., 1998; Artana, 2016).

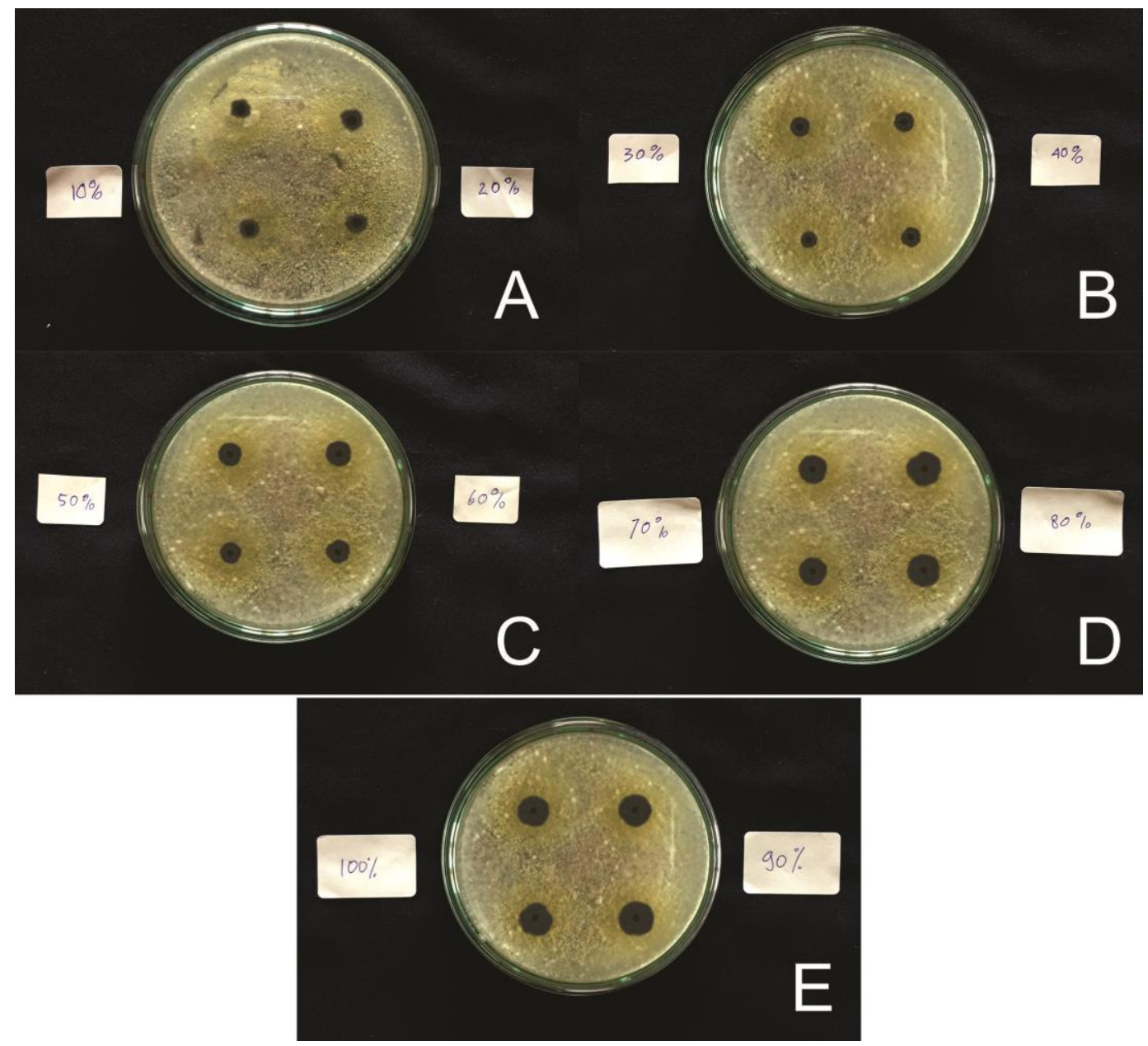

Gambar 3. Zona hambat daun murbei terhadap Aspergillus flavus

Keterangan: (a): Konsentrasi 10\% \& 20\% (b): Konsentrasi 30\% \& 40\% (c): Konsentrasi 50\% \& 60\% (d): Konsentrasi $70 \%$ \& $80 \%$ (e): Konsentrasi $90 \%$ \& 100\%

\section{Uji Total Populasi Aspergillus flavus}

Uji total populasi Aspergillus flavus dilakukan setelah mendapat konsentrasi ekstrak tertinggi, dalam penelitian ini yaitu ekstrak dengan konsentrasi $80 \%$. Hasil penelitian menunjukan bahwa ekstrak daun murbei $80 \%$ dapat menghambat pertumbuhan Aspergillus flavus. Penhambatan ektrak daun murbei terhadap populasi Aspergillus flavus, pada kontrol yang telah diinkubasi selama 5 hari, populasi Aspergillus flavus yang tumbuh adalah 2,6 x $10^{7}$ CFU/ml. Pada Aspergillus flavus yang telah ditambahkan ekstrak 80\% setelah masa inkubasi 5 dan 10 hari terjadi penurunan populasi Aspergillus flavus menjadi $1,9 \times 10^{7} \mathrm{CFU} / \mathrm{ml}$ dan $1,3 \times 10^{7}$ $\mathrm{CFU} / \mathrm{ml}$. 
Hasil ini menunjukan bahwa semakin lama waktu inkubasi maka semakin banyak jumlah penurunan populasi Aspergillus flavus, hal ini sesuai dengan Waluyo (2011) bahwa semakin lama inkubasi maka jumlah mikroba yang mati semakin banyak. Hal ini dikarenakan senyawasenyawa flavonoid, alkaloid, polifenol yang berperan sebagai aktivitas antikapang yang terdapat pada ekstrak daun murbei dapat menghambat pertumbuhan Aspergillus flavus.

\section{KESIMPULAN DAN SARAN}

\section{Kesimpulan}

Berdasarkan hasil penelitian yang telah dilakukan maka dapat disimpulkan beberapa hal sebagai berikut :

1. Ekstrak daun murbei mampu menghambat pertumbuhan Aspergillus flavus pada konsentrasi 10\%, 20\%, 30\% dengan kategori lemah, konsentrasi 40\%, 50\%, 60\%, 70\%, $100 \%$ dengan kategori sedang dan konsentrasi $80 \%, 90 \%$ dengan kategori kuat.

2. Konsentrasi penghambatan tertinggi untuk menghambat pertumbuhan Aspergillus flavus adalah pada konsentrasi $80 \%$ dengan diameter penghambatan 11, $95 \mathrm{~mm}$ dengan kategori kuat.

\section{Saran}

Berdasarkan hasil penelitian yang telah dilakukan maka dapat disarankan sebagai berikut :

1. Perlu dilakukan penelitian lebih lanjut untuk melakukan penerapan ekstrak daun murbei ke dalam produk pangan yang tercermar Aspergillus flavus.

\section{DAFTAR PUSTAKA}

Anita, A., S. Khotimah, dan A.H., Yanti, 2014. Aktivitas Antibakteri Ekstrak Daun Benalu Jambu Air (Dendropthoe pentandra (L.) Miq) terhadap Pertumbuhan Salmonella typhi. Jurnal Protobiont. 3 (2) : 268-272.

Apriyanto, A., 2002, Toksisitas Akut Ekstrak Etanol Daun Mimba (Azadirachta indica A. Juss.) pada Mencit, Skripsi, xvi, Fakultas Farmasi Universitas Sanata Dharma, Yogyakarta.

Artana, I. G. S., I.B.G., Darmaya sa, dan Meitini, W.P., 2016, Daya Hambat Ekstrak Kasar Daun Kaliandra (Calliandra calothyrsus Meissn.) Terhadap Jamur Kontaminan Pada Pakan Konsentrat Ayam Ras Pedaging, Simbiosis, 4 (2): 31-38.

Charista, I.P. 2012. Profil kapang yang diisolasi dari saluran pernapasan pasien yang menjalani pemeriksaan Mikologi Di Laboratorium Parasitologi FKUI RSCM.Skripsi. Fakultas Kedokteran, Universitas Indonesia. Jakarta

Davis, W.W., dan T.R. Stout. 1971. Disc Plate Method of Microbiological Antibiotic Assay, Appl. Microbiol. 4 (22), 666670

Elsie, B. H dan M.S. Dhanarajan. 2010. Evaluation of Antimicrobial Activity and Phytochemical Screening of Gelidium acerosa. Research and Development Centre, Bharathiar University, India.

Ganiswarna, S., 1995, Farmakologi dan Terapi, edisi IV, 271-288 dan 800-810, Bagian Farmakologi Fakultas Kedokteran Universitas Indonesia, Jakarta. 
Martin, E.A. 2012. Kamus Sains. Alih bahasa oleh Ahmad Lintang Lazuardi. Jakarta: Pustaka Pelajar.

Nuryani. 2011. Uji potensi isolat lokal Aspergillus flavus sebagai penghasil aflatoksin. Bogor: Departemen Penerbit ITP IPB.

Parhusip, A.J.N., 2006. Kajian Mekanisme Antibakteri Ekstrak Andaliman (Zanthoxylum acanthopodium DC) Terhadap Bakteri Patogen Pangan. Disertasi. Sekolah Pascasarjana. Bogor. Institut Pertanian Bogor.

Pelczar, Michael J dan Chan, E. C. S. 1998. Dasar-Dasar Mikrobiologi Jilid II. Jakarta: UI Press.

Permadi, A. 2006. Tanaman Obat Pelancar Air Seni. Jakarta: Penebar Swadaya.

Pitt, J.I., and A.D. Hocking. 1997.Fungi and Food Spoilage. Blackie Academic \& Profesional. London.

Rahmawati D., 2004, Mempelajari Aktivitas Antioksidan dan Antimikroba Ekstrak Antarasa (Lisea cubeba) dan Aplikasinya Sebagai Pengawet Alami Pada Bahan Pangan, Skripsi (tidak dipublikasikan), Institut Pertanian Bogor.

Sunanto, H. 2009. 100 Resep Sembuhkan Hipertensi, Obesitas dan Asam Urat. Jakarta: PT. Gramedia.

Varley JC. and Reddish GF. The phenol coefficient as a measure of the practical value of disinfectants. Appl Microbiol; 22 (4) : 215-225.

Waluyo L. 2008. Teknik dan Metode Dasar dalam Mikrobiologi. Malang: UMM Press. 